\title{
In Vivo Study of Nutritive Value of Oil Seeds from New Varieties of Sunflower, Safflower and Groundnut
}

\section{SHORT COMMUNICATION}

\section{Satish Ingale*, S.K. Shrivastava}

Department of Applied Chemistry, Government Engineering College, Jabalpur- 482011 (M.P.), India

\begin{abstract}
The nutritive value of new varieties of oil seeds has been assessed in a series of feeding trial with 34 days old 18 white rats supported moderate rat growth (male albino). The nutritive values of five new varieties of oil seeds, viz sunflower ( Helianths annuus L.) variety LSF -11 and LSF-8, safflower (Carthamus tinctorius L.) variety PBNS-12 and PBNS-40, and groundnut (Arachis hypogaea L.) variety JL-24 were determined and compared in terms of the total feed intake, faeces voided, feed utilization, percent of feed utilization, nitrogen intake, nitrogen voided, nitrogen utilization, percent of nitrogen utilization, protein efficiency ratio and feed efficiency ratio per rat per day were reported in ranged between 6.56 to $8.03,1.20$ to 1.48 , 5.26 to $6.55,80.15$ to $82.70,0.25$ to $0.32,0.02$ to $0.028,0.23$ to $0.30,90.75$ to $92.89,(+) 1.37$ to $(+) 1.51$ and $(+) 0.35$ to $(+) 0.37$ percent respectively. These new varieties of oil seeds were found non-toxic for rats and supported moderate rat growth.
\end{abstract}

Received on: 17 Jul. 2011

Accepted on: 31 Jul. 2011

Published on: 1 Aug. 2011

DOI: $10.5195 /$ iioablett.2011.2

Keywords: Nutritive value; oil seeds, Helianths annuus; Carthamus tinctorius; Arachis hypogaea; In vivo

\section{INTRODUCTION}

All living organisms need food for growth, work, repair and maintaining the life process. Oil seeds constitute one of the largest potential sources of protein in the world and play a vital in the Human diet (McKevith, 2005). The nutritional quality of a protein is determined by the amino acid composition and the digestibility of that protein. Biological assay measure the efficiency of biological utilization of dietary protein as source of the essential amino acid under a set of standard condition. A biological assay of the quality of a particular protein, measured as the gain in weight of an animal per gram of the protein taken. Recently, many methods have been developed for obtaining nutritive value by comparing protein efficiency ratio (PER), relative protein value (RPV), net protein ratio (NPR) and a modified protein efficiency ratio. Two methods are widely used in the determination of nutritive value, these are Growth methods (PER, NPR, RPV) and Nitrogen balance methods (Apparent digestibility (AD), true digestibility (TD), net protein utilization and biological value) (Hackler, 1977).

High nutritive value to oil seeds like groundnut is attributed to the presence of biologically active compounds such as, tocopherols, flavonoids, phytosterols, resveratrol, relatively high level of protein and their easy oil digestibility (Venkatachalam and Sathe, 2006; Tuberoso et al., 2007). Recently, several attempts have been made to produce new cultivars with improved nutritional qualities (Jonnala et al., 2005). A balanced diet is one which contains all the essential nutrients like carbohydrates, fats, proteins, minerals and vitamins in the correct proportion for the normal growth and development of the body (Babji et al., 2010; Balsubramanian et al., 1980). The protein Advisory Group (World Health Organization/Food Agricultural Organization/UNICEF) pointed out that in the selection of protein mixtures suitable for supplement diets, attention must be paid to factors such as, the nutritive value of the individual ingredients and the final product, avoiding the possibility of the presence of toxic or interfering substances which reduce the nutritive value, the desirability using products of local origin, low cost, good keeping qualities and acceptability (Joint FAO/WHO Expert Consultation, 2007; Arnold, 1980).

The main objective of this research is to investigate the nutritive value of sunflower variety LSF-11 and LSF-8, safflower variety PBNS-12 and PBNS-40 and groundnut variety JL-24. It will also provide knowledge on the nutritional implication of feeding on staples of low nutritive quality. 


\section{MATERIALS AND METHODS}

\section{Sample Collection}

The field experiment is conducted on sunflower variety LSF-11 and LSF-8, safflower variety PBNS-12 and PBNS40 and groundnut variety JL-24. The seeds under investigation were procured from Oil Seeds Research Station, Latur (Maharashtra), Marathwada Agricultural University, Parbhani and Mahatma Phule Krishi Vidyapeeth, Jalgaon (Maharashtra).

\section{Experimental Setup}

The experiment was performed on the white male albino rats. Eighteen rats 34 days old were distributed in six groups of three rats, each selected rats were of body weight nearest to the mean of population. They were housed in individual cages. The rats were fed ad-libitum exclusively experimental diets for 10 days (Bressani et al.,
1977) including the three days of pre experimental period and water was available ad-libitum.

The experimental diets were isonitrogenious (24.50 $\mathrm{g} / 100 \mathrm{~g}$ ) and isocaloric (3030 kcal/ $\mathrm{kg}$ of balanced diet). The balance diet (Table-1) comprised per kg:- $420 \mathrm{~g}$ maize yellow, $50 \mathrm{~g}$ oil, $430 \mathrm{~g}$ groundnut cake, $80 \mathrm{~g}$ fish meal (Jawala), $19.6 \mathrm{~g}$ mineral mixture and 0.49 vitamin mixture as recommended by Indian Standards Institution (565.4 part I 1970). Casein and seed proteins were added to this basal diet by substitution of the maize yellow to give a total dietary protein content of $100 \mathrm{~g} / \mathrm{kg}$. The seed meals used in the study were autoclaved for 30 minutes at $15 \mathrm{1b}$ pressure (Kaduskar and Netke, 1978) before being incorporated in the diets to destroy the toxic constituents (Cyanogenetic glycosides, tannin, trypsin inhibitors and haemagglutinins).

Table 1. Composition of experimental diet and balanced diet

\begin{tabular}{|c|c|c|c|c|c|c|}
\hline \multirow{2}{*}{ Diet Ingredients } & \multirow{2}{*}{$\begin{array}{c}\text { Balanced } \\
\text { Diet }\end{array}$} & \multicolumn{2}{|c|}{ Sunflower } & \multicolumn{2}{|c|}{ Safflower } & \multirow{2}{*}{$\begin{array}{c}\text { Groundnut } \\
\text { JL-24 }\end{array}$} \\
\hline & & LSF- 11 & LSF- 8 & PBNS- 12 & PBNS- 40 & \\
\hline Maize Yellow & 420 & 380 & 380 & 320 & 320 & 380 \\
\hline Fat & 50 & 70 & 70 & 90 & 90 & 70 \\
\hline Groundnut Cake & 430 & 400 & 400 & 410 & 410 & 400 \\
\hline Powder of sample & - & 50 & 50 & 80 & 80 & 50 \\
\hline Fish Meal (Jawala) & 80 & 80 & 80 & 80 & 80 & 80 \\
\hline Mineral mixture & 19.6 & 19.6 & 19.6 & 19.6 & 19.6 & 19.6 \\
\hline Vitamin mixture & 0.4 & 0.4 & 0.4 & 0.4 & 0.4 & 0.4 \\
\hline Metabolic energy & 3053.10 & 3029.94 & 3028.03 & 3029.49 & 3030.86 & 3032.91 \\
\hline Calculated protein (\%) & 24.89 & 24.55 & 24.54 & 24.43 & 24.44 & 24.56 \\
\hline Analysed protein (\%) & 25.21 & 24.40 & 24.12 & 24.11 & 24.34 & 25.25 \\
\hline
\end{tabular}

The animal testing work was approved by animal ethical committee at Department of Nutrition, College of Veterinary Sciences and Animal Husbandry, Jabalpur.

\section{Analysis}

The weight and food intake of the rats were monitored daily. Faeces were collected between days 5 to 10 days on the trial. The fecal matter (excreta) was dried in hot oven at $100^{\circ} \mathrm{C}$. Protein efficiency ratio and feed efficiency ratio were calculated by the method given by (Osborne et al., 1919). Total nitrogen intake and nitrogen voided were estimated by semi-micro Kjeldahl method (Person, 1973).

\section{Statistical Analysis}

Results of $H$. annuus variety LSF-11 and LSF-8 and C. tinctorius variety PBNS-12 and PBNS-40 were analyzed for statistical report by using 'student $t$ test'. Descriptive statistics (Mean, standard error mean and standard deviation) were calculated for triplicate determination using the SPSS 10 computer software package and significant differences within treatments were determined using $5 \%$ significance level.

\section{RESULTS AND DISCUSSIONS}

In the present experiment feed intake denotes the food consumed in last three days. Feed intake, faces voided, 
feed utilization, percentage of feed utilization, nitrogen utilization, nitrogen intake, nitrogen voided, nitrogen utilization and percentage of nitrogen utilization per rat per day are given in Table-2. Gain in body weight, total feed consumed, total protein consumed protein efficiency ratio and feed efficiency ratio per rat for 10 days are given in Table-3.

In the collection period of three days the total feed intake, faeces voided, feed utilization, percent of feed utilization, nitrogen intake, nitrogen voided, nitrogen utilization and percent of nitrogen utilization per rat per day were found to be in ranged between 6.56 to 8.03 , 1.20 to $1.48,5.26$ to $6.55,80.15$ to $82.70,0.25$ to $0.32,0.02$ to $0.03,0.23$ to 0.30 and 90.75 to 92.89 percent respectively in the seeds of $H$. annuus variety LSF-11 and LSF-8, C. tinctorius variety PBNS-12 and PBNS-40 and A. hypogaea variety JL-24. Crude protein content and other proximate constituent are not affected by autoclaving (Gupta et al., 1988) and protein digestibility is enhanced by four to forty percent as compared to raw material (Sangle et al., 1993).

Table 2. Feed and nitrogen intake by experimental animal

\begin{tabular}{|c|c|c|c|c|c|c|c|c|}
\hline Diet of selected samples & $\begin{array}{l}\text { Feed } \\
\text { intake } \\
\text { (g) }\end{array}$ & $\begin{array}{l}\text { Faeces } \\
\text { voided } \\
\text { (g) }\end{array}$ & $\begin{array}{l}\text { Feed } \\
\text { utilization } \\
\text { (g) }\end{array}$ & $\begin{array}{l}\text { Feed } \\
\text { Utilization } \\
(\%)\end{array}$ & $\begin{array}{l}\text { Nitrogen } \\
\text { intake } \\
\text { (g) }\end{array}$ & $\begin{array}{l}\text { Nitrogen } \\
\text { voided } \\
\text { (g) }\end{array}$ & $\begin{array}{l}\text { Nitrogen } \\
\text { utilization } \\
\text { (g) }\end{array}$ & $\begin{array}{l}\text { Nitrogen } \\
\text { Utilization } \\
(\%)\end{array}$ \\
\hline Balanced Diet & 7.87 & 1.62 & 6.52 & 79.41 & 0.32 & 0.03 & 0.28 & 89.37 \\
\hline Sunflower (LSF-11) & 6.82 & 1.35 & 5.47 & 80.19 & 0.27 & 0.03 & 0.24 & 90.75 \\
\hline Sunflower (LSF-8) & 6.56 & 1.30 & 5.26 & 80.15 & 0.25 & 0.02 & 0.23 & 91.50 \\
\hline Safflower (PBNS-12) & 7.18 & 1.24 & 5.94 & 82.70 & 0.28 & 0.02 & 0.26 & 92.82 \\
\hline Safflower (PBNS-40) & 6.92 & 1.20 & 5.72 & 82.66 & 0.27 & 0.02 & 0.25 & 92.89 \\
\hline Groundnut (JL-24) & 8.03 & 1.48 & 6.55 & 81.61 & 0.32 & 0.028 & 0.30 & 91.27 \\
\hline
\end{tabular}

Table 3. Gain in body weight, total protein consumed, protein efficiency ratio and feed efficiency ratio

\begin{tabular}{|c|c|c|c|c|c|c|}
\hline Diet of selected samples & $\begin{array}{c}\text { Protein in diet } \\
\text { (\%) }\end{array}$ & $\begin{array}{c}\text { Gain in Body } \\
\text { wt (g) }\end{array}$ & $\begin{array}{l}\text { Total feed } \\
\text { consumed } \\
\text { (g) }\end{array}$ & $\begin{array}{c}\text { Total protein } \\
\text { consumed } \\
\text { (\%) }\end{array}$ & $\begin{array}{l}\text { Protein efficiency } \\
\text { ratio(PER) } \\
(\%)\end{array}$ & $\begin{array}{c}\text { Feed efficiency } \\
\text { ratio(FER) } \\
(\%)\end{array}$ \\
\hline Balanced Diet & 25.21 & 26.91 & 78.72 & 19.85 & 1.36 & 0.34 \\
\hline Sunflower (LSF-11) & 24.40 & 24.49 & 68.16 & 16.63 & 1.47 & 0.36 \\
\hline Sunflower (LSF-8) & 24.12 & 23.78 & 65.63 & 15.83 & 1.50 & 0.36 \\
\hline Safflower (PBNS-12) & 24.11 & 26.13 & 71.84 & 17.32 & 1.51 & 0.36 \\
\hline Safflower (PBNS-40) & 24.34 & 25.21 & 69.22 & 16.85 & 1.50 & 0.37 \\
\hline Groundnut (JL-24) & 25.25 & 27.73 & 80.28 & 20.27 & 1.37 & 0.35 \\
\hline
\end{tabular}

The feed utilization for $H$. annuus variety LSF-11 and LSF-8, C. tinctorius variety PBNS-12 and PBNS-40 and $A$. hypogaea variety JL-24 was found to be 5.47, 5.26, 5.94, 5.72 and $6.55 \mathrm{~g}$, respectively. However, nitrogen utilization for these varieties was found to be $0.24,0.23$, $0.26,0.25$ and $0.30 \mathrm{~g}$, respectively.

The value of feed utilization and nitrogen utilization of these varieties was found to be in close resemblance with the values of feed utilization (6.52g) and nitrogen utilization $(0.28 \mathrm{~g})$ of controlled diet and also with other

varieties of oil seeds (Gupta and Shrivastava, 2003; Nagraj, 1995; Singh et al., 2000; Shrivastava et al., 1991).

The gain in body weight, total feed consumed and total protein consumed for $H$. annuus variety LSF-11 and LSF8, C. tinctorius variety PBNS-12 and PBNS-40 and A. hypogaea variety JL-24 were found to be in ranged 
between 23.78 to $27.73,65.63$ to 80.28 and 15.83 to $20.27 \mathrm{~g}$, respectively.

The protein efficiency ratio of all the five varieties under study are in general accordance with one another i.e. 1.47 (LSF-11), 1.50 (LSF-8), 1.51 (PBNS-12), 1.50 (PBNS40) and 1.37 (JL-24) and also with controlled diet 1.36. Also the feed efficiency ratio for $H$. annuus variety LSF11 and LSF-8, C. tinctorius variety PBNS-12 and PBNS-40 and $A$. hypogaea variety JL-24 was found to be $0.36,0.36$, $0.36,0.37$ and 0.35 , respectively. The value of feed efficiency ratio for there varieties was found to be in close resemblance with 0.34 of controlled diet, these five varieties under study showed almost same nutritive value in spite of having different chemical composition. It may be due to isonitrogeneous inclusion of crude protein of oil seeds (Shrivastava et al., 1991; Gupta and Shrivastava, 2003).

Table 4 shows the statistical report of $H$. annuus varieties LSF-11 and LSF-8 indicating non-significant result with respect to all parameters. Similarly the statistical report of C. tinctorius varieties PBNS-12 and PBNS-40 indicating non-significant result with respect to all parameters except percent nitrogen utilization and feed efficiency ratio.

Table 4. Statistical analysis of diet samples of sunflower (LSF11 and LSF-8) and safflower (PBNS-12 and PBNS-40)

\begin{tabular}{|c|c|c|c|c|c|c|c|c|c|c|c|c|c|}
\hline Experimen & Feed & Faeces & Feed & Feed & Nitrogen & Nitrogen & Nitrogen & Nitrogen & Gain in & Total & Total & Protein & Feed \\
\hline \multirow[t]{3}{*}{ tal diet } & intake & voided & utilization & utilization & intake & voided & utilization & Utilization & body & feed & protein & efficiency & efficiency \\
\hline & (g) & (g) & (g) & (\%) & (g) & (g) & (g) & $(\%)$ & wt & consumed & consumed & ratio (\%) & ratio (\%) \\
\hline & & & & & & & & & (g) & (g) & (\%) & & \\
\hline Sunflower & 6.82 & 1.35 & 5.47 & 80.19 & 0.27 & 0.03 & 0.24 & 90.75 & 24.49 & 68.16 & 16.63 & 1.47 & 0.36 \\
\hline \multicolumn{14}{|l|}{ (LSF-11) } \\
\hline Sunflower & 6.56 & 1.30 & 5.26 & 80.15 & 0.25 & 0.02 & 0.23 & 91.50 & 23.78 & 65.63 & 15.83 & 1.50 & 0.36 \\
\hline \multicolumn{14}{|l|}{ (LSF-8) } \\
\hline Mean & 6.66 & 1.33 & 5.36 & 80.17 & 0.26 & 0.02 & 0.24 & 91.16 & 24.13 & 66.90 & 16.23 & 1.49 & 0.36 \\
\hline S.E.(m) & 0.05 & 0.01 & 0.05 & 0.01 & 0.003 & 0.001 & 0.002 & 0.170 & 0.159 & 0.568 & 0.179 & 0.006 & 0.001 \\
\hline S.D. & 0.13 & 0.03 & 0.113 & 0.023 & 0.01 & 0.01 & 0.010 & 0.42 & 0.39 & 1.39 & 0.44 & 0.02 & 0.00 \\
\hline S.L. at $5 \%$ & $0.12 *$ & 0.00 & 0.00 & 0.00 & 0.00 & 0.00 & 0.00 & 0.00 & 0.00 & 0.00 & 0.00 & 0.00 & 0.01 \\
\hline Safflower & 7.18 & 1.24 & 5.94 & 82.70 & 0.28 & 0.02 & 0.26 & 92.82 & 26.13 & 71.84 & 17.32 & 1.51 & 0.36 \\
\hline \multicolumn{14}{|l|}{ (PBNS-12) } \\
\hline Safflower & 6.92 & 1.20 & 5.72 & 82.66 & 0.27 & 0.02 & 0.25 & 92.89 & 25.21 & 69.22 & 16.85 & 1.50 & 0.37 \\
\hline \multicolumn{14}{|l|}{ (PBNS-40) } \\
\hline Mean & 7.05 & 1.22 & 5.83 & 82.68 & 0.27 & 0.19 & 0.25 & 92.88 & 25.67 & 70.53 & 17.09 & 1.50 & 0.36 \\
\hline S.E.(m) & 0.06 & 0.01 & 0.05 & 0.010 & 0.00 & 0.00 & 0.00 & 0.02 & 0.21 & 0.59 & 0.10 & 0.00 & 0.00 \\
\hline S.D. & 0.14 & 0.02 & 0.12 & 0.02 & 0.00 & 0.00 & 0.00 & 0.06 & 0.50 & 1.43 & 0.26 & 0.010 & 0.00 \\
\hline S.L. at $5 \%$ & 0.00 & 0.010 & 0.00 & 0.00 & 0.00 & 0.00 & 0.00 & $0.14 *$ & 0.00 & 0.00 & 0.00 & 0.00 & $0.10 *$ \\
\hline
\end{tabular}

S.E. $(m)$ - Standard error mean, S.D. - Standard deviation, S.L at $5 \%$ - Significance level at $5 \%,{ }^{*}$ Significan

\section{CONCLUSION}

Five new varieties of oil seeds were found non-toxic for rats. The results of the present nutritional studies with rats suggest that they could be more widely grown and utilized as dietary protein sources and these could be put to far greater use. Their potential for nutritional exploitation is further enhanced by the fact that they would not require prolonged and expensive heattreatment prior to use. Similarly these seeds presently are being used in oil production and for human and animal feeding. Produce seeds of high N content and no 
measurable toxicity and thus have good potential for development.

\section{ACKNOWLEDGEMENTS}

We are thankful to Dr. S. K. Mukharjee, Professor, Department of Nutrition, College of Veterinary Sciences and Animal Husbandry, Jabalpur, Dr. Manju Gupta, Assistant Professor, Department of Chemistry, Home science college, Jabalpur and Mr. S. K. Shinde, Department of Statistic MPSC, Maharashtra, for their co-operation.

\section{REFERENCES}

Arnold E (1980) Dictionary of Nutrition and Food Technology, Nutrition and Dietetic foods, pp.98.

Babji AS, Fatimah S, Abolhassani Y, Ghassem M (2010) Nutritional quality and properties of protein and lipid in processed meat products a perspective. International Food Research Journal, 17: 35-44.

Balsubramanian SC, Ramasashtri BV, Gopalan C (1980) National Institute of Nutrition, Indian council of Medical Research, Hyderabad, 3: 28.

Bressani R, Elias LG, Malina MR (1977) E studios sober la digestibilidad de la proteina de $v$ arias e species de leguminosas. Archives Latino-American de Nutrition, 27: 215-231.

Gupta M, Shrivastava SK (2003) Nutritive value of some new varieties of oil seeds. Ultra Science,15: 281-284.

Gupta R, Shrivastava JP, Gupta BS, Dutta KS (1988) Indian Journal of animal Health, 27: 21-25.

Hackler LR (1977) Methods of measuring protein quality: A review of Bioassay procedures, Cereal Chemistry, 54: 984-995.

Joint FAO/WHO Expert Consultation (2007) Protein quality evaluation in human diets, Rome: Food and Agriculture Organization.

Jonnala R, Dunford N, Dashiell K (2005) New high oleic peanut cultivars grown in the Southwestern US, Journal of American Oil Chemistry Society, 85: 125-128.

Kaduskar MR, Netke SP (1978) Paper presented at $6^{\text {th }}$ Annual
Symposium of the Indian Poultry Science Association Souvenir, 19.

McKevith B (2005) Nutritional aspects of oilseeds, British Nutrition Foundation Bulletin, 30: 13-26.

Nagraj G (1995) Quality and Utility of oil seeds, Directorate of oil seeds research (ICRA) Hyderabad.

Osborne TB, Mendal LB, Feery EL (1919) A method for expressing numerically the growth promoting of a protein, Journal of Biological Chemistry, 37: 223-229.

Person D (1973) Laboratory Technique in Food Analysis, London, pp. $48-49 \& 57$.

Sangle M, Devi R, Pawar VD, Arya A (1993) Processing Modulation of Soymilk Flavor Chemistry. Journal of Draying Food, Home Sciences, 12: 113-119.

Shrivastava SK, Bajpai RK, Khan AG (1991) Nutritive value of five new varieties of pigeon pea (Cajanus cajan L., Mill. Sp.) in poultry ration. Ultra scientist, 3: 78-81.

Singh JN, Rajesh K, Pankaj K, Singh PK (2000) Status of dietary fibers in new millennium-A review. The Indian Journal of Nutritional Dieted, 37: 261-273.

Tuberoso C, Kowalczyk A, Saeeitzu E, Cabras P (2007) Determination of antioxidant compounds and antioxidant activity in commercial oil seeds for food use. Journal of Food Chemistry, 103: 1494-1501.

Venkatachalam M, Sathe SK (2006) Chemical composition of selected edible nut seeds. Journal Agricultural, Food Chemistry, 54: 4705-4714.

\section{AUTHORS}

\section{Satish Ingale, MSc}

He is currently a Ph.D. scholar in Applied Chemistry at Rajiv Gandhi Technical University, Bhopal, India, under guidance of Dr. S.K. Shrivastava. His research include natural product. He has authored 7 publications.

\section{S.K. Shrivastava, MSc, PhD}

He is Professor and Head of the Department of Applied Chemistry, Government Engineering College, Jabalpur, Bhopal, India. His research include natural product. He has 65 publications in this credit.

\section{ULIS D-Senke}

This journal is published by the University Library System of the University of Pittsburgh

as part of its D-Scribe Digital Publishing Program, and is cosponsored by the University of Pittsburgh Press. 